\title{
ENTERRAMIENTOS REGIOS EN CASTILLA Y LEÓN (C. 842-1504). LA DISPERSIÓN DE LOS ESPACIOS FUNERARIOS Y EL FRACASO DE LA MEMORIA DINÁSTICA ${ }^{1}$
}

\author{
ROYAL BURIALS IN CASTILE AND LEON (C. 842-1504). \\ THE SPREAD OF FUNERARY SPACES AND THE FAILURE \\ OF DYNASTIC MEMORY
}

\author{
FERNANDO ARIAS GUILLÉN \\ Universidad del País Vasco/Euskal Herriko Unibertsitatea
}

\begin{abstract}
Resumen: La ausencia de un mausoleo regio en Castilla similar a Saint-Denis o Westminster se ha considerado, de manera tradicional, fruto del desinterés de los monarcas castellanos en las ceremonias funerarias y de las fronteras movedizas de un reino siempre en expansión. En el presente artículo se pretende analizar los espacios funerarios de la monarquía castellanoleonesa durante toda la Edad Media y plantear las causas que impidieron la consolidación de un único panteón dinástico. A lo largo de estas líneas se reexaminará el papel de la Reconquista en este proceso y se mostrará que la dispersión de espacios funerarios y la no consolidación de un único mausoleo regio fue resultado de las circunstancias concretas que se dieron entre mediados del siglo XIII y finales del XIV, período en el que el resto de reinos occidentales sí crearon sus propios panteones dinásticos.
\end{abstract}

\begin{abstract}
The absence of a royal mausoleum in Castile similar to Saint-Denis or Westminster has been traditionally considered a result of the kings' disinterest in funerary ceremonials and a consequence the changing boundaries of an expanding kingdom. The current article aims to analyse the funerary spaces of the CastilianLeonese monarchy during the Middle Ages and to suggest the main obstacles to the consolidation of a dynastic royal mausoleum. This paper will re-examine the role of the Reconquisrta in this process and will try to show how the spread of funerary spaces and the non-consolidation of a centralized royal mausoleum was the consequence of specific circumstances between the second half of the thirteenth and the end of the fourteenth century, the period when the rest of Western monarchies created their own mausoleums.
\end{abstract}

\footnotetext{
${ }^{1}$ Este trabajo ha sido posible gracias a la Ayuda para Contratos de Formación Posdoctoral, concedida por el Ministerio de Economía (Ref: FPDI-2013-15847), y los proyectos de investigación De la Lucha de Bandos a la hidalguía universal: transformaciones sociales, políticas e ideológicas en el País Vasco (siglos XIV y XV), financiado por el Ministerio de Economía (ref. HAR2013-44093-P), y Grupo Consolidado de Investigación. Sociedad, poder y cultura, del Gobierno Vasco (ref. IT-600-13). Quiero darles también las gracias a Chris Given-Wilson, por sus útiles comentarios y sugerencias, y a Marta Serrano y Fermín Miranda, cuya ayuda, orientación y amabilidad ha sido inestimable.

Abreviaturas utilizadas: $\mathrm{AHN}=$ Archivo Histórico Nacional; cap. $=$ capítulo; doc.$=$ documento; par. = párrafo; vol. $=$ volumen .
} 
Palabras clave: Edad Media; Castilla; enterramientos regios; mausoleo real; Reconquista
Keywords: Middle Ages; Castile; royal burials; royal mausoleum; Reconquista.

\section{SUMARIO}

1. Introducción.- 2. La dispersión de los espacios funerarios. Un reino en permanente cambio (842-1199).- 3. La no consolidación de un mausoleo dinástico (11991369).- 4. La creación de nuevos espacios funerarios en la época Trastámara (13691504).- 5. El fracaso de una memoria dinástica. Castilla frente a otras monarquías europeas.- 6. Bibliografía citada.

\section{INTRODUCCIÓN}

En 1312, Fernando IV falleció de manera inesperada en plena campaña. Según la Crónica de Alfonso XI, no estaba muy claro qué hacer con su cadáver, así que se llevó á enterrar el cuerpo del Rey Don Fernando (...) á la ciubdat de Córdoba, que era cerca dende; ca non le podian levar á Toledo nin á Sevilla por razon de las muy grandes calenturas que facia ${ }^{2}$. La rápida y poco ceremoniosa sepultura del monarca, junto con las dudas acerca de dónde debía ser enterrado, hacen que el deceso de Fernando IV ejemplifique, aunque de manera extrema, la escasa importancia que, supuestamente, tendrían los enterramientos regios en Castilla.

Los célebres trabajos de Ricardo del Arco sobre los sepulcros reales en Aragón y Castilla marcaron el inicio de los estudios sobre los enterramientos regios en España a mediados del siglo $\mathrm{XX}^{3}$. Sin embargo, fue a partir de finales de la década de 1980 cuando la historiografía hispana dedicó especial atención a los principales aspectos que rodeaban la muerte de un monarca ${ }^{4}$. Desde entonces, han proliferado los estudios sobre los funerales regios y, en especial, sobre los distintos mausoleos y cementerios reales. Existe unanimidad en considerar que los reyes castellanos no concedieron apenas importancia a sus ceremonias de enterramiento, pero se encuentran notables diferencias a la hora de interpretar el motivo de esta situación. Estas divergencias se deben a las dos opuestas concepciones de la monarquía castellana que existen: una institución que seguía los mismos principios doctrinales que sus homólogas occidentales o un caso completamente excepcional en el panorama europeo.

\footnotetext{
${ }^{2}$ Rosell 1953b, p. 173.

${ }^{3}$ Del Arco 1945, 1954.

${ }^{4}$ Mitre 1988. Un completo recorrido sobre el estado de la cuestión puede encontrarse en Guiance 1998 .
} 
José Manuel Nieto considera que la corona castellana también proyectó en sus entierros un discurso ideológico en el que se resaltaba la inmortalidad de la institución regia, de manera similar a los monarcas franceses. Esta interpretación sigue la línea de su concepción amplia sobre la sacralidad, en la que la unción regia juega un papel subsidiario, por lo que sostiene que el carácter divino de la realeza castellana era tan evidente e innegable que no necesitaba de este tipo de ceremonias. Además, el autor no duda en que la monarquía castellana también tuvo sus propios panteones; el problema radicaría en una concepción muy reduccionista sobre lo que es un mausoleo regio, teniendo como único modelo a Saint-Denis ${ }^{5}$.

En cambio, otros investigadores consideran que la monarquía castellana constituía un modelo propio de realeza, diferente al de Francia o Inglaterra, como Adeline Rucquoi ${ }^{6}$, Denis Menjot ${ }^{7}$ o Ariel Guiance ${ }^{8}$. Según este autor, los monarcas castellanos no crearon un ceremonial funerario basado en la inmortalidad regia como sus homólogos franceses, sino que se limitaron a mostrar un ritual de la muerte que proyectaba los ideales regios de piedad y sabiduría. La fortaleza del poder real en Castilla hacía por completo innecesarios este tipo de ceremoniales y la creación de un panteón regio al estilo de Saint-Denis o Westminster. La monarquía castellana no era sagrada, sino que su legitimación se basaba en la secular tarea de la Reconquista y la continuidad del reino godo?.

En fechas más recientes, autores como Xabier Dectot ${ }^{10}$, Gerardo Boto $^{11} \mathrm{o}$ Raquel Alonso ${ }^{12}$ han estudiado los lugares de enterramiento regios de manera específica pero siguiendo similares ejes interpretativos ${ }^{13}$. Así, Raquel Alonso desarrolla la línea argumental de Adeline Rucquoi y Ariel Guiance al afirmar que la elección de dichos lugares respondió al deseo de mostrar la continuidad dinástica desde época visigoda y que la multiplicidad de espacios funerarios se debió a un discurso basado en la acumulación de lugares no simbólicos, no a su confrontación ${ }^{14}$.

Considero que la oposición antagónica entre similitud y excepcionalidad respecto a un modelo "ideal", el que constituirían la monarquía

\footnotetext{
${ }^{5}$ Nieto 1993, cap. 6; 1997, pp. 50-51.

${ }^{6}$ Rucquoi 1992.

${ }^{7}$ Menjot 2003.

${ }^{8}$ Guiance 1998.

${ }^{9}$ Guiance 1998, pp. 306-324.

${ }^{10}$ Dectot 2004, 2005.

${ }^{11}$ Boto 2004, 2012.

${ }^{12}$ Alonso 2007, 2012.

${ }^{13}$ Cabrera 2001, 2011.

${ }^{14}$ Alonso 2007, par. 1 y 36.
} 
francesa e inglesa, limita las posibilidades de análisis de la corona castellana. La cuestión no radica en considerar si los reyes castellanos seguían un modelo común o constituían una excepcionalidad, sino que, a la hora de construir un modelo de realeza europeo, es necesario tener en cuenta el caso castellano. No se puede limitar el análisis a discutir si existe una mera adecuación a ciertos cánones, ya que la construcción y representación del poder regio en Castilla, al igual que en cualquier otro reino, era una realidad mucho más fluida, donde elementos particulares y comunes se entremezclaban y en el que se constatan evidentes influencias de variados orígenes.

Por tanto, este estudio pretende mostrar una visión más dinámica de los enterramientos regios a través un análisis comparativo entre la propia Castilla y otros reinos peninsulares y ultrapirenaicos. En lugar de presentar la dispersión de espacios funerarios y la creación de un mausoleo dinástico como dos soluciones diferentes, que respondían a realidades monárquicas distintas, se estudiará de manera paralela la evolución de las prácticas funerarias en Castilla y otros lugares a lo largo de la Edad Media.

La consolidación de un lugar como único panteón regio no constituía una tarea sencilla. Para que eso sucediera, la importancia de la memoria dinástica debía imponerse sobre los deseos personales de cada monarca, quienes gustaban de individualizar su figura a través de un enterramiento particular en un sitio por el que tuviera especial devoción o que simbolizara el éxito de su reinado. El afianzamiento de un mausoleo fue, de ese modo, un complejo y largo proceso, no siempre lineal, en lugar de una situación natural incontestada. A partir de la segunda mitad del siglo XIII, Saint-Denis y Westminster alcanzaron dicha categoría, mientras que las monarquías aragonesa, navarra y portuguesa consolidaron sus cementerios dinásticos a finales del siglo XIV. En cambio, en Castilla siguió predominando la multiplicidad de espacios funerarios hasta el siglo XVI. Los monarcas castellanos crearon y remodelaron diferentes panteones personales o familiares, pero, a diferencia de sus homólogos peninsulares y europeos, ninguno alcanzó una posición preeminente. De ese modo, se pretende demostrar que el no afianzamiento de alguno de los múltiples lugares de enterramiento regio como el mausoleo único e incontestado de la monarquía respondió a una serie de causas concretas del período comprendido entre la segunda mitad del siglo XIII y finales del XIV, no a una imposibilidad ontológica.

La Reconquista tuvo una importancia clave y fundamental en Castilla y León desde todos los puntos de vista, pero sin llegar al extremo en que ésta explica por sí sola toda su evolución histórica, sin establecer diferencias cronológicas o tener en cuenta otros factores. En primer lugar, habría que diferenciar el doble sentido del término, Reconquista como proceso de expansión de los reinos cristianos y como discurso ideológico justificativo del 
mismo $^{15}$. La conquista de nuevos territorios y el desplazamiento del centro político que eso podía producir explican, en parte, la dispersión de tumbas reales, pero esos cambios en la fisonomía del reino no fueron exclusivos de la monarquía castellano-leonesa, como se observará. Por otra parte, el deseo de algunos reyes castellanos de recibir sepultura en lugares relacionados con sus gestas militares sí constituyó un elemento particular y que, sin duda, dificultaba la consolidación de un único mausoleo regio, al potenciar la memoria individual de cada rey en lugar de la dinástica. No obstante, dicho discurso ideológico no siempre estuvo presente ni fue la única causa que condicionó las decisiones de los monarcas, por lo que tampoco explica esta situación por sí solo. Como se mostrará en las próximas páginas, hubo otros factores que impidieron la consolidación de un espacio funerario preeminente: la ausencia de un antepasado santo en la genealogía regia que sirviera de nexo común a todos los monarcas, la escasa (por no decir nula) implantación de la práctica del doble enterramiento y, sobre todo, los conflictos que atravesó la monarquía durante este período, en el que se puso en duda la legitimidad de varios reyes ${ }^{16}$.

Hay un último elemento que también hay que tener en cuenta: el azar. La consolidación de un único mausoleo regio no siempre responde a una intención determinada de un monarca en un momento concreto, sino que muchas veces se produce de manera un tanto fortuita, cuando sus sucesores deciden continuar con dicha tradición, como muestra el caso de San Lorenzo de El Escorial, que no fue creado originalmente con tal intención ${ }^{17}$. En otras ocasiones, los deseos funerarios de algunos reyes no se cumplieron, ya fuera que un lugar concreto albergase también los restos mortales de sus descendientes o incluso la elección de su última morada. Resulta complicado integrar el azar en el discurso histórico, pero también hay que tenerlo presente. En este caso, no se pretende defender el surgimiento de mausoleos regios como una cuestión meramente aleatoria, ni mucho menos, sino que se incorporará a la argumentación para mostrar que el afianzamiento de un panteón dinástico en Castilla no constituía una opción imposible, sino fruto de un contexto histórico determinado, por lo que, quizás, con unas circunstancias diferentes, podría haberse conseguido.

\footnotetext{
${ }^{15}$ Un excelente análisis sobre la evolución del término en García Fitz 2010.

${ }^{16}$ Véase Nieto 2006; Arias 2012.

${ }^{17}$ Varela 1990, pp. 23-24.
} 


\section{LA DISPERSIÓN DE LOS ESPACIOS FUNERARIOS. UN REINO EN PERMANENTE CAMBIO (842-1199)}

Aunque se pensaba que los reyes visigodos se enterraron en la iglesia de Santa Leocadia de Toledo, posiblemente se trate de un mito, pues no hay ninguna información que constate dicha práctica. De ese modo, dichos monarcas dispusieron sus tumbas en sus propiedades, siguiendo la tradición de la alta nobleza goda y la aristocracia hispanorromana del Bajo Imperio. Tras la invasión musulmana, los primeros monarcas asturianos actuaron de manera similar hasta el reinado de Alfonso II (791-842), quien creó un panteón regio en la iglesia de Santa María de Oviedo, el cual se convirtió en el centro de una red funeraria que se extendía por todo el reino. Oviedo se constituyó en el centro político del reino astur, desplazando a Pravia, y se convirtió en la nueva Toledo dentro del discurso goticista de la monarquía ${ }^{18}$.

Los sucesores de Alfonso II se enterraron también en Oviedo durante las décadas siguientes, pero, a partir de Ordoño II (†924), optaron por León, síntoma del nuevo desplazamiento del centro político del reino fruto de la expansión hacia el sur. Dicha elección no se cuestionó siquiera por el temor a los ataques de Almanzor, que llegaron al corazón del reino ${ }^{19}$. León se convirtió así en el lugar de sepultura de los monarcas asturleoneses durante más de un siglo, que eligieron la iglesia de Santa María, el monasterio de San Salvador de Palat y, finalmente, el monasterio de San Isidoro como última morada. En 1024, Alfonso V reedificó el templo de San Pelayo y San Juan Bautista pero el impulso de este edificio como panteón regio se produjo con Fernando I, momento en que se cambió la advocación del monasterio por la de San Isidoro, tras el solemne traslado de los restos mortales de dicho santo y sus reliquias desde Sevilla en 1063. Fernando I cambió su primera decisión de enterrarse en Arlanza para presentarse como continuador del linaje de los reyes leoneses, por lo que optó por el mausoleo familiar en León, que incluía, entre otras figuras, a Vermudo II $(\dagger 999)$ y Alfonso V $(\dagger 1028)^{20}$. Durante los siguientes 150 años, el panteón experimentó numerosas reformas y recibió a varios miembros de la familia real, pero no se consolidó como el mausoleo por antonomasia de la monarquía. A pesar de los esfuerzos de la infanta Urraca, hija de Fernando I y Sancha, por conmemorar la memoria de sus progenitores,

${ }^{18}$ Deswarte 2003, p. 67; Alonso 2005, p. 363; 2007, par. 2; 2012, p. 205.

${ }^{19} \mathrm{El}$ posterior relato de Pelayo, obispo de Oviedo, en el que se refería el traslado de vuelta a su ciudad de los cuerpos de los monarcas por temor a dichas incursiones es, con toda probabilidad, una invención, creada con ánimo de cuestionar la decisión de transferir la capitalidad del reino a León. Dectot 2005, pp. 81-84.

${ }^{20}$ Alonso 2007, par. 16; Boto 2012, p. 539; Dectot 2005, pp. 84-85; Deswarte 2003, pp. 175 y 215 . 
en la segunda mitad del siglo XII el antiguo cementerio de los reyes se convirtió en una capilla funeraria abierta también a la aristocracia leonesa. Posiblemente esta situación determinó la decisión de los reyes de León de enterrarse en Santiago de Compostela. En el primer tercio del siglo XIII, el mausoleo fue reformado de nuevo, incluyendo los monumentos al conde García de Castilla $(\dagger 1029)$ y a Sancho III de Navarra $(\dagger 1035)$, en lo que se ha interpretado como una maniobra para aumentar el prestigio de la colegiata en dicha coyuntura política, al imprimirle una orientación pro-castellana que atrajera el interés de Fernando III, al que se le recordaría la anterior unión de las dos coronas bajo su ancestro homónimo ${ }^{21}$.

La unión de los dos reinos había desplazado el centro político a la Tierra de Campos, lo que condicionó la elección de sepultura de sus sucesores. Además, tras la breve separación de los reinos entre 1065 y 1072, estos volvieron a unirse con Alfonso VI, quien además expandió sus dominios de manera significativa hasta conquistar Toledo en 1085. García, efímero rey de Galicia, fue enterrado en San Isidoro $(† 1071)$ junto con su padre y Sancho II, rey de Castilla, en el monasterio de Salvador de Oña (†1072). Alfonso VI eligió Sahagún como lugar de sepultura, a pesar de la enorme fuerza simbólica de Toledo. El carácter fronterizo de la antigua capital visigoda, con el evidente peligro que ello conllevaba, no fue el único motivo que influyó la decisión de Alfonso VI, pues tal elección se debió, sobre todo, a que dicha localidad fue el centro político y el foco de renovación cultural durante su reinado ${ }^{22}$.

Urraca I fue enterrada en San Isidoro de León (†1126) tras un conflictivo reinado pero sería el último monarca en descansar allí, pues su hijo, Alfonso VII, optó por Toledo $(† 1157)$, a pesar de que había prometido hacerlo en Santiago de Compostela junto a su padre, Raimundo de Borgoña. Aunque la base de su poder al inicio de su reinado se hallaba en Galicia, su definitivo asentamiento en el trono y la ceremonia de coronación de 1135 en León como Imperator totius Hispaniae explican tal decisión de claro carácter neogoticista. A su muerte, la nueva separación de los reinos de Castilla y León volvió a alterar el panorama político. Sancho III murió tras apenas un año en el trono y fue enterrado junto a su padre en Toledo, mientras que los reyes de León decidieron crear su propio espacio funerario en Santiago de Compostela.

Como se mencionó anteriormente, la metamorfosis que experimentó San Isidoro de León en la segunda mitad del siglo XII posiblemente disuadió a Fernando II (†1188) de elegir la colegiata como su lugar de descanso eterno,

\footnotetext{
${ }^{21}$ Sánchez Ameijeiras 2005.

${ }^{22}$ Walker 2001, p. 152; Garcia 2009, par. 3, 5 y 26.
} 
y ya desde 1180 había decidido que él y sus sucesores serían enterrados en Santiago de Compostela. Dicha disposición fue llevada a cabo, no sin dificultad, por su hijo, Alfonso IX, quien también recibió sepultura allí (†1230). Fue durante su reinado cuando se creó el cementerio real, pues ordenó la elaboración de esculturas yacentes de la emperatriz Berenguela y de Raimundo de Borgoña, con el ánimo de enfatizar la continuidad dinástica. De esta manera, Alfonso IX reiteraba su derecho sucesorio, que llegó a ser cuestionado por Sancho López, y asentó la memoria de su linaje, que se vinculaba a la figura del apóstol ${ }^{23}$.

Alfonso VIII no siguió los pasos de su padre y abuelo, sino que decidió crear su propio panteón regio. El monarca fundó el monasterio cisterciense de las Huelgas en Burgos, terminado en 1199, se comprometió a enterrarse allí con su mujer, Leonor de Plantagenet, y expresó su deseo de que sus hijos y descendientes siguiesen su consejo y mandato. La erección de un monasterio junto al palacio suponía reproducir en Burgos el modelo leonés u ovetense, pero con el deseo de mostrar la imagen de una nueva monarquía emergente, diferenciada de la leonesa, y que se presentaba como campeona de la Cristiandad. Resulta significativo en ese sentido que se utilice el castillo como emblema heráldico por primera $\mathrm{vez}^{24}$. El monasterio de las Huelgas guardaba, por tanto, bastantes paralelismos con Fontevraud, lugar de reposo de los reyes angevinos, y quizás sirvió de inspiración para Blanca de Castilla, reina de Francia, a la hora de fundar la abadía cisterciense de Royaumont ${ }^{25}$. Por otra parte, la elección de Burgos resultaba lógica porque, durante el reinado de Alfonso VII, el poder regio era mucho más intenso en esa zona, y por la enorme importancia de la localidad para la monarquía le llevó a recibir el título de "cabeza de Castilla" (caput Castelle) ${ }^{26}$.

Si detenemos en este momento el relato, se observa que estos tres siglos y medio han estado caracterizados por la dispersión funeraria. A pesar de la creación de varios cementerios reales, ninguno se ha consolidado como único lugar de enterramiento de la monarquía. No obstante, en 1199, la situación de los reyes de Castilla y León no supone, en modo alguno, una situación excepcional respecto a la de sus homólogos europeos, ya que ningún panteón se había afianzado de manera indiscutida en esa fecha.

${ }^{23}$ Boto 2012, pp. 541-542; Calderón 2011, p. 183; Núñez 1999, pp. 17-24, 98-100 y 119-120.

${ }^{24}$ Sánchez Ameijeiras 1998,pp. 86 y 101-102.

${ }^{25}$ Abad 2001, p. 65; Cerda 2012, p. 636; Gómez Bárcena 2005, pp. 51 y 55-56; Valle 2005 , pp. 35-40; Yarza 2005, pp. 16-17. Rose Walker, en cambio, reduce la influencia de Leonor de Inglaterra en el proyecto y considera que el monasterio burgalés estaría inspirado en otros modelos peninsulares, como el monasterio de Sigena. Walker 2005.

${ }^{26}$ Estepa, Álvarez Borge, Santamarta 2011,pp. 33 y 58. 
Ese mismo año, Ricardo I fue enterrado en Fontevraud, el mismo lugar que albergaba el cuerpo de su padre, Enrique II (†1189), pero fue el último monarca inglés que pudo elegir la abadía angevina como lugar de descanso eterno, merced a la conquista francesa de Anjou y Normandía tan sólo cinco años después. Las coronaciones de los reyes ingleses se realizaron en Westminster desde 1066 casi de manera ininterrumpida, pero no así los funerales. Eduardo el Confesor sí fue sepultado allí, pero sus sucesores eligieron otras iglesias que habían fundado o patrocinado ellos mismos: Guillermo el Conquistador se enterró en Caen $(\dagger 1087)$, Guillermo Rufus $(\dagger 1100)$ en Winchester, Enrique I en Reading $(\dagger 1135)$ y Esteban I en Faversham $(\dagger 1154)^{27}$.

En Francia, a pesar de la visión interesada que podía transmitir Suger sobre Saint-Denis, no estaba tan claro que ése fuera el único lugar posible de enterramiento de los reyes franceses. Luis VI sí fue sepultado allí (†1137), ganándose la alabanza del cronista, pero su padre, Felipe I, fue enterrado en la abadía de Saint-Benoît-sur-Loire $(† 1108)^{28}$. Aunque Suger consideraba que el monarca tomó esta decisión al considerarse indigno de reposar allí, en realidad respondía a la línea de actuación política de los capetos, quienes buscaban agrandar el dominio regio, por lo que optar por dicho lugar era una manera de asentar su autoridad sobre unos territorios recientemente incorporados. A principios del siglo XIII, la consolidación de Saint-Denis como mausoleo regio no era una realidad, de hecho, el último monarca francés, Luis VII, se había enterrado en la abadía cisterciense de Barbeau (†1180). Incluso Luis IX coqueteó con la idea de enterrarse en la propia Barbeau o en Royaumont ${ }^{29}$.

Aragón tampoco contaba con un único panteón regio en este momento. Ramiro $(\dagger 1063)$ y Sancho Ramírez $(† 1094)$ se enterraron en San Juan de la Peña, pero la conquista de Huesca hizo que Alfonso I ( $† 1134)$ ya optara por la antigua ciudad romana, donde trasladó también el obispado. En 1194, Alfonso II expresó en su testamento su deseo de recibir sepultura en el monasterio cisterciense de Poblet y que éste se convirtiera en el mausoleo regio. Sin embargo, su voluntad no se cumpliría hasta dos siglos más adelante, ya que varios de sus sucesores optaron por otros emplazamientos ${ }^{30}$.

Los primeros monarcas de Portugal, Alfonso Henriques $(† 1185)$ y Sancho I (†1211), se enterraron en el monasterio de Santa Cruz de Coímbra, centro intelectual del discurso ideológico sobre la legitimidad del emergente reino luso, pero Alfonso II ( $† 1223)$ creó su propio panteón en el monasterio de Alcobaça, síntoma del desplazamiento de la zona de poder al sur y del deseo

\footnotetext{
${ }^{27}$ Hallam 1982, p. 369; Palliser 2004, pp. 1-2.

${ }^{28}$ Cusimano, Moorhead 1992, cap. XIII y XXXIV.

${ }^{29}$ Erlande-Brandenburg 1975, p. 68; Hallam 1982, p. 372.

${ }^{30}$ Buesa 1996, pp. 19-20.
} 
del monarca de individualizar su memoria, tras los enfrentamientos con sus hermanas a raíz de la sucesión de su padre ${ }^{31}$.

Los reyes de Navarra primero se enterraron en San Esteban de Deyo y luego en Nájera, pero la pérdida de la localidad y la crisis de 1134 llevaron a la búsqueda de un nuevo lugar de sepultura para la monarquía: Santa María de Pamplona. García Ramírez $(† 1150)$ y Sancho VI $(† 1194)$ fueron enterrados allí. Sin embargo, la consolidación definitiva de la seo pamplonesa como mausoleo dinástico tuvo que esperar, ya que Sancho VII, cuya situación jurídica y política era más estable que la de sus inmediatos antecesores debido al reconocimiento papal de 1197, decidió hacerlo en Roncesvalles (†1234), en la colegiata que había financiado ${ }^{32}$.

La ausencia de un único mausoleo se ha considerado reflejaba el deseo de los monarcas castellanos, quienes querrían que sus tumbas marcaran un territorio siempre en expansión ${ }^{33}$. Sin embargo se observa que, a principios del siglo XIII, la ausencia de un único panteón regio en Castilla no supone una situación excepcional en el panorama europeo. La pérdida de territorios, como en el caso inglés o navarro, la adquisición de nuevos, como en Portugal o Aragón, o la expansión del dominio regio, como en el caso de Francia, también provocaron el desplazamiento del centro político y la multiplicación de los espacios funerarios de cada reino. Los cambios territoriales motivaron una evidente dispersión funeraria, pero ésta no fue la única razón de la misma. Los deseos personales de cada monarca, especialmente el propósito de individualizar su figura, resultaron aún más decisivos. En ese sentido, podría considerarse la importancia de la Reconquista desde su vertiente ideológica, como discurso propagandístico de la monarquía. Dicha influencia se puede observar en las decisiones de algunos reyes, sobre todo Fernando I o Alfonso VII, pero no parece un elemento constante ni definitorio: hasta la fecha, ningún monarca eligió su lugar de enterramiento en una ciudad que él hubiera (re)conquistado o en base a un hito militar. Aunque pueda resultar obvio, en este período se observa un evidente elemento común en Castilla respecto a otros reinos: la elección del lugar de sepultura estaba influido, de manera primordial, por la base territorial del poder regio. El desplazamiento de Oviedo a León, la elección de Sahagún por Alfonso VI, en lugar de la recuperada Toledo, con toda la carga simbólico que arrastraba, o la creación del monasterio de las Huelgas se pueden interpretar en ese sentido. El carácter feudal de la monarquía ${ }^{34}$ hacía que, a pesar de tener un dominio nominal sobre todo el territorio, ejerciera su

\footnotetext{
${ }^{31}$ Vasconcelos 2012, pp. 161-164.

${ }^{32}$ Miranda 2008, pp. 271 y 277.

${ }^{33}$ Alonso 2012, p. 223.

${ }^{34}$ Pascua 2001, p. 112. Sobre esta cuestión véase el clásico Estepa 1989.
} 
autoridad de manera más intensa y evidente en unos lugares que en otros. En ese sentido, la corona castellana no difería mucho de sus homólogas europeas, afrontando similares problemas en el largo proceso de asentamiento del poder regio que caracterizó estos siglos.

\section{LA NO CONSOLIDACIÓN DE UN MAUSOLEO DINÁSTICO (1199-1369)}

Resulta curioso que fuera de España se da por hecho que las Huelgas fue el mausoleo regio de los monarcas castellanos, hasta el punto de que incluso se llega a considerar que serviría de inspiración a Eduardo I para convertir Westminster en un foco de culto a la monarquía similar ${ }^{35}$. El monasterio burgalés acogió a numerosos miembros de la familia real durante los siglos siguientes, pero los únicos monarcas que reposan allí son Alfonso VIII $(† 1214)$ y su hijo, Enrique I $(† 1217)^{36}$. Alfonso IX de León también sería el último monarca en hacerlo en la sede apostólica. Se podría hacer un breve ejercicio de historia contra-factual y considerar que, en ambos casos, se habían desarrollado unos mausoleos con un potente discurso dinástico y una marcada simbología de la identidad de ambos reinos, por lo que, quizás, si el devenir histórico hubiera sido diferente, habrían consolidado su estatus. Pero no fue así. En las décadas siguientes, la nueva (y definitiva) unión de Castilla y León y la gran expansión en Andalucía cambiaron por completo la fisonomía del reino una vez más y abortó la posibilidad de estos lugares de convertirse en los panteones dinásticos.

Fernando III volvió a unir las coronas de Castilla y León y expandió los límites del reino hasta conquistar Sevilla en 1248. Cuatro años después el monarca falleció, pero su deseo era proteger en la otra vida lo que había conquistado en ésta, por lo que optó por enterrarse en la ciudad hispalense antes que en Toledo o en Burgos ${ }^{37}$. En su último testamento, Alfonso X (†1284) expresó su deseo de recibir sepultura en el monasterio de Santa María la Real de Murcia, pero facultó a sus albaceas a hacerlo en Sevilla si así lo estimaban

${ }^{35}$ Hallam 1982, p. 371. Elizabeth Hallam, a partir de la clásica obra sobre Alfonso VIII de J. González, afirmó que las Huelgas fue concebido como lugar de entierro y de coronación de los reyes castellanos, pero obvió que la coronación era una ceremonia muy excepcional en Castilla y que su rol como mausoleo fue muy efímero. En la actualidad, la historiografía inglesa sigue dando por correcta dicha afirmación. Sobre la influencia de las Huelgas en Eduardo I véase Palliser 2004, pp. 6-7.

${ }^{36}$ De las 32 personas allí enterradas, todas pertenecieron a la familia real salvo una tal María de Almenar, quien se cree pudo ser hija de Armengol, conde de Urgel. Gómez Bárcena 2005, p. 57.

${ }^{37}$ Así explicaron dicha decisión los obispos del reino al Papa diez años más tarde. Linehan 1993, p. 451. 
oportuno, como al final ocurrió, si bien el corazón del monarca sí se trasladó a Murcia ${ }^{38}$.

La necesidad de legitimarse tras su conflictivo acceso al trono provocó que Sancho IV se desvinculase de la memoria de su padre e individualizara su propia figura, decidiendo enterrarse en Toledo, la misma ciudad donde se coronó y a la que dispensó un trato especial durante su reinado (1284-1295) ${ }^{39}$. Fernando IV fue llevado a Córdoba tras su repentina muerte en 1312 y, en 1350, el cuerpo Alfonso XI fue depositado en Sevilla do yazian otros rreyes sus anteçesores, aunque su deseo era reposar en la misma ciudad que su pa$\mathrm{dre}^{40}$. Por su parte, el cadáver del depuesto Pedro I se quedaría en Montiel, lugar de su muerte en 1369, siendo posteriormente trasladado a Madrid y, finalmente, a Sevilla ya en $1877^{41}$.

Más de un siglo y medio después de la muerte de Alfonso VIII, parecía evidente que el monasterio de las Huelgas no se había afianzado como el principal mausoleo regio de los monarcas castellanos. Sin embargo, tampoco Toledo, Sevilla u otra ciudad del reino podían arrogarse tal condición. En el último tercio del siglo XIV la dispersión de los espacios funerarios de la corona castellana seguía siendo evidente. Dicha diversidad, ahora sí, constituía una situación excepcional si se compara con los otros reinos europeos del entorno.

En Inglaterra se produjo un cambio en la elección del lugar de enterramiento a partir de Juan I (†1216), pues se buscó la vinculación con alguna santidad en lugar de recibir sepultura en una casa religiosa sobre la que el monarca había ejercido su patronazgo. La devoción por san Wulfstan llevó a dicho monarca a optar por Worcester, mientras que la decisión de enterrarse en Westminster de Enrique III ( $† 1272)$ fue propiciada por su deseo de vincularse con la figura de Eduardo el Confesor. Las ambiciosas reformas que este monarca emprendió en Westminster y el desarrollo del culto al Confesor han llevado a plantear que Enrique III tenía la intención de crear un panteón regio similar al de Saint-Denis, pero tal afirmación resulta muy dudosa. La consolidación de Westminster se produjo durante los reinados de Eduardo I (1272-1307), tras perder interés en la abadía de Vale Royal una vez fallecida su esposa Leonor, y de Eduardo III, quien, tras contemplar brevemente la idea de recibir sepultura en Colonia junto a los Reyes Magos, optó por hacerlo en la abadía londinense "entre sus ancestros, los reyes de Inglaterra,

\footnotetext{
${ }^{38}$ González Jiménez 2004, p. 365.

${ }^{39}$ Rosell 1953a, pp. 89-90. La decisión de enterrarse allí la adoptó a poco de comenzar su reinado, en 1285. Gutiérrez 1997, p. 165.

${ }^{40}$ Orduña 1994, vol. I, p. 6.

${ }^{41}$ Del Arco 1954, pp. 304-306.
} 
de gloriosa memoria". A pesar de ello, la convulsa historia política inglesa propició algunas excepciones a esta tendencia. Los depuestos Eduardo II (1307-1327) y Ricardo I (1377-1399) fueron enterrados, respectivamente, en Gloucester y Kings Langley, para evitar que se generara un culto hacia su figura, aunque el último fue trasladado a Westminster en 1413, cumpliendo su deseo de ser enterrado junto a Eduardo el Confesor. Por su parte, Enrique IV decidió vincularse a la figura de santo Tomás Becket y recibir sepultura en Canterbury ( $† 1413)$, aunque su hijo, Enrique V, volvió a optar por la abadía londinense $(\dagger 1422)^{42}$. Por tanto, Westminster se convirtió en el mausoleo regio por antonomasia en Inglaterra a partir del último cuarto del siglo XIII, pero su asentamiento definitivo estuvo salpicado de diversos avatares y no fue una decisión tan firme e incuestionable como se podría creer a simple vista.

La definitiva consagración de Saint-Denis como panteón regio de la monarquía francesa tuvo lugar también en fechas similares. En 1223, el funeral de Felipe Augusto supuso un hito destacado en el desarrollo del ceremonial funerario de los reyes franceses, pero fue el reinado de Luis IX el momento de mayor importancia en dicho proceso. En la década de 1260, el futuro san Luis reorganizó el mausoleo real, creando tumbas y efigies de todos sus ancestros, tanto carolingios como capetos, para crear un discurso de continuidad de la institución monárquica. Su canonización en 1298 constituyó el aldabonazo definitivo para el templo, pues convirtió al monarca en una figura central de la memoria regia en Francia. Todos sus sucesores hasta el siglo XVIII fueron enterrados en Saint-Denis, con la excepción de Luis XI (†1483), que optó por Notre-Dame de Cléry ${ }^{43}$.

Después de Alfonso II, los reyes aragoneses se enterraron en el monasterio de Santa María de Sijena (Pedro II, †1213), en el de Santes Creus (Pedro III, $† 1287$ y Jaime II, $† 1327$ ), en Barcelona (Alfonso III, $\uparrow 1291$ ) o Lleida (Alfonso IV, $\uparrow 1336$ ) hasta que Pedro IV convirtió Poblet en el panteón dinástico.

El Ceremonioso mostró siempre predilección por el monasterio cisterciense por lo que decidió recibir sepultura allí. Su decisión rompía la tradición franciscana de sus inmediatos antecesores, quizás porque la idea de humildad no casaba bien con su política de exaltación del poder regio, si bien tal medida no sólo respondió a motivos devocionales. El deseo de vincularse a sus antepasados que allí descansaban, Alfonso II y, sobre todo, su admirado sant rei Jaime I, influiría también poderosamente en el ánimo del monarca.

${ }^{42}$ Burden 2003, p. 37; Carpenter 1996, pp. 458-459; Duffy 2003, p. 18; Given-Wilson 2009, p. 270; Palliser 2004, pp. 2-14.

${ }^{43}$ Erlande-Brandenburg 1975, pp. 18, 76 y 81-83. 
Además, la ubicación del monasterio, situado en un lugar céntrico entre Zaragoza y Barcelona, también resultaba muy conveniente ${ }^{44}$.

Pedro IV (†1387) concibió su lugar de descanso como un panteón dinástico, por lo que integró a sus predecesores en su plan sepulcral y estableció que sus sucesores fueran también enterrados allí. Para ello, ordenó a sus vasallos que no jurasen fidelidad a los nuevos monarcas si antes no había decidido recibir sepultura en el monasterio cisterciense. El testamento de Juan I (†1396) contravino tal disposición, pues deseaba enterrarse en el monasterio de Monserrat y que sus vísceras fueran a Poblet, pero Martín I decidió cumplir la voluntad de su padre por encima de la de su hermano, reforzando el carácter dinástico del panteón ${ }^{45}$.

La llegada de los Trastámara no hizo sino consolidar a Poblet como el mausoleo de los reyes de Aragón. El deseo de reforzar la legitimidad de los nuevos monarcas provocó incluso que Juan II situara a su padre, Fernando I $(† 1416)$, en el lugar que le correspondería a Martín I (†1410). De ese modo, el primer monarca Trastámara tendría una posición más preeminente y, además, se mostraría la continuidad dinástica ${ }^{46}$.

En el caso luso, Dinis I (1279-1325) dejó de lado el monasterio de Alcobaça e intentó resaltar su figura y basar su poder en un nuevo discurso ideológico, creando un mausoleo regio similar a Saint-Denis en el monasterio de Odivelas en torno al culto de dicho santo, que trajo a Portugal desde Francia. Su intento no tuvo continuidad en sus sucesores, quienes eligieron Lisboa (Alfonso IV, en 1357 y Fernando I, en 1383) o volvieron a Alcobaça (Pedro I, en 1367). Tras el período de interregno y el triunfo de Juan I de Avís, el monasterio de Batalha se asentó como panteón regio, legitimando a la nueva dinastía a través de la providencial victoria de Aljubarrota (1385) ${ }^{47}$.

En Navarra, las crisis dinásticas de 1234 y 1328 ayudaron a que la catedral de Pamplona se consolidase definitivamente como mausoleo dinástico. La muerte sin descendencia de Sancho VII llevó al trono a Teobaldo I $(† 1253)$ gracias al apoyo de la nobleza y en contra de los deseos del Fuerte, quien había prohijado a Jaime I de Aragón. Esa cuestionada legitimidad le impulsó a enterrarse en Pamplona, para así vincularse al mismo espacio sacro que sus antecesores. Los avatares dinásticos provocaron que esta decisión

${ }^{44}$ Serrano 2015a, pp. 402-404. La obra se encuentra en prensa en este momento, por lo que quiero darle las gracias a Marta Serrano por su enorme amabilidad y permitirme leer su trabajo antes de su publicación.

${ }^{45}$ Serrano 2015 a, pp. 416 y 422; Del Arco 1945 , pp. 58-59 y 288-289.

${ }^{46}$ Serrano 2015a, p. 423. Sobre el enterramiento de Fernando I y sus problemas de ubicación véase Serrano 2015b, a quien le agradezco de nuevo que me permitiera leer el artículo antes de que vea la luz.

${ }^{47}$ Mattoso 1995, pp. 404-405; Vasconcelos 2012, pp. 167-170. 
no siempre tuviera continuidad entre sus inmediatos sucesores. Teobaldo II $(† 1270)$ recibió sepultura en Champaña y la posterior unión de las coronas francesa y navarra bajo la dinastía capeta significó que dichos monarcas optaron por Saint-Denis. La llegada al trono de los Évreux volvió a convertir la catedral pamplonesa en el principal escenario de la realeza navarra, al ser el lugar de coronación y de enterramiento de los monarcas. Carlos II $(† 1387)$ recibió sepultura en la seo y ordenó la construcción de una capilla para albergar los restos de su padre, Felipe III $(† 1343)$, que también descansaban allí. Por su parte, Carlos III (†1425) ordenó la realización de un monumento sepulcral para él y su esposa, Leonor Trastámara, símbolo del afianzamiento de la catedral pamplonesa como mausoleo dinástico ${ }^{48}$.

En el período que transcurre desde mediados del siglo XIII hasta finales del XIV, el resto de monarquías europeas tuvieron un lugar de enterramiento privilegiado que se terminó afianzando como mausoleo dinástico, pero no sucedió así en Castilla. Considerar que la no consolidación de un mausoleo regio fue el resultado del escaso interés que tendrían los monarcas castellanos por sus lugares de enterramiento es una presunción errónea. En la segunda mitad del siglo XIII, tanto Alfonso X como Sancho IV prestaron una enorme atención a los espacios funerarios de la Corona. En apenas dos décadas, estos monarcas adecentaron o renovaron los sepulcros de varios de sus antecesores entre los siglos XI y XIII. El Sabio fue el encargado de la gestación de la Capilla Real de Sevilla, donde se enterró a su padre Fernando III, y del traslado desde las Huelgas, en 1279, del cuerpo de su esposa, Beatriz de Suabia. El monasterio burgalés también sería reorganizado por dicho rey, donde recibió sepultura su primogénito, Fernando de la Cerda. Además de estas intervenciones, realizó otras ceremonias que entroncaban la continuidad de la monarquía con sus orígenes remotos, como el traslado de Pelayo a Covadonga (1270) o el entierro de Wamba en Toledo (1274). Sancho IV encomendó la sepultura y estatua de su padre en Sevilla, los sepulcros de Alfonso VI y Sancho II en Sahagún y Oña y, sobre todo, la fundación de la capilla de Santa Cruz en Toledo. Hoy en día inexistente tras las reformas efectuadas a principios del siglo $\mathrm{XVI}$, fue el lugar donde se emplazaría la tumba del propio monarca y donde se trasladaron los restos de Alfonso VII, Sancho III y el exiliado Sancho II de Portugal ${ }^{49}$.

\footnotetext{
${ }^{48}$ Miranda 2014; Osés 2008,pp. 305 y 315; Ramírez Vaquero 2008, pp. 279 y 297; Tamburri 1996, p. 395. Quiero darle las gracias a Fermín Miranda por su ayuda y orientación en este tema y por permitirme usar su trabajo aún inédito.

${ }^{49}$ Alonso 2003, pp. 472-478, 2007, par. 24-26; Gómez Bárcena 2005, p. 67; Gutiérrez 1997, pp. 143-169; Laguna 2001, p. 240; Linehan 1993, pp. 459-460; Martínez de Aguirre 1995, p. 119.
} 
Este interés en preservar y resaltar los espacios funerarios de la monarquía muestra la dispersión de dichos lugares. Una de las razones que explican esta variedad es el deseo de los reyes de individualizar su memoria, tendencia que resulta antagónica con el afianzamiento de un mausoleo regio unificado. En ese sentido, el discurso ideológico de la Reconquista y el deseo de los monarcas de resaltar las gestas militares que se realizaron durante su reinado tuvieron un peso específico importante en este período. Fernando III fue enterrado en Sevilla, ciudad que conquistó y que mejor simbolizaba su exitoso reinado. Alfonso X, a pesar de que recibió sepultura junto a su padre, primero pensó en ser enterrado en Cádiz y después en Murcia, el primero logar que Dios quiso que ganásemos a seruicio dél y a onrra del rrey don Ferrando $^{50}$. El deseo de Alfonso XI de que sus restos mortales reposaran en Córdoba respondía a un deseo similar. En 1343 ordenó construir la iglesia de San Hipólito, ya que nació el día de su festividad, para conmemorar su célebre victoria sobre los meriníes en la batalla del Salado tres años antes. Sin embargo, el edificio aún no estaba concluido cuando el monarca falleciós ${ }^{51}$. No obstante, tanto el Sabio como el Onceno fueron enterrados en Sevilla, aunque este último de manera temporal, por lo que quizás resulte sugerente plantear la hipótesis de que Sevilla pudo convertirse en el mausoleo dinástico de los monarcas castellanos en este momento.

Tras la conquista de Sevilla y la definitiva anexión de la zona occidental de Andalucía a mediados del siglo XIII, las adquisiciones territoriales de la monarquía castellana durante los próximos dos siglos serían mínimas, por lo que la fisonomía del reino no sufrió alteraciones como las acaecidas en épocas anteriores. Además, tras el reinado de Fernando III se observa cierta visión de que la Reconquista había llegado a su fin, si bien la posterior invasión benimerín y consolidación del reino de Granada cambiarían dicha percepción. La descripción de la Estoria de España de la muerte de Fernando III y el epitafio que Alfonso X ordenó inscribir en su tumba en la capilla real de Sevilla apuntan a esta concepción, al recordar que el monarca conquistó toda España $^{52}$.

${ }^{50}$ González Jiménez 2004, p. 364.

${ }^{51}$ En 1728, Felipe V obtuvo una bula de Benedicto XIII para incorporar la ya colegiata de San Hipólito a la capilla real que había fundado Enrique II en 1371. Los cuerpos de Fernando IV y Alfonso XI fueron trasladados a dicha iglesia colegial el 8 de agosto de 1736. Benavides 1860, vol. II, doc. DLXXXVI; García Fernández 1988, doc. 376; Ramírez 1856, pp. 208-209.

${ }^{52}$ Según la crónica, Fernando III le diría a su hijo en su lecho de muerte: "sennor te dexo de toda la tierra de la mar aca, que los moros del rey Rodrigo de Espanna ganado ovieron; et en tu sennorio finca toda: la una conquerida, la otra tributada. Sy la en este estado en que te la yo dexo la sopieres guardar, eres tan buen rey commo yo; et sy ganares por ti mas, eres meior que yo; et si desto menguas, non eres tan bueno commo yo"; Menéndez Pidal 1977, vol. II, pp. 772-773. 
Un elemento fundamental para la consolidación de los mausoleos regios en Westminster y Saint-Denis fue la presencia de un monarca santo allí enterrado. Las figuras de Eduardo el Confesor y Luis IX se convirtieron en modelos ideales para articular la memoria dinástica, por lo que los monarcas ingleses y franceses podían reforzar su propia legitimidad al resaltar la continuidad de un linaje con tan insignes predecesores. En Castilla no había ningún antecesor similar, pero Fernando III se acercaba muchísimo a este paradigma.

Los aniversarios de la muerte del rey eran motivo de conmemoración, hasta el punto que, en octubre de 1258, Inocencio IV otorgó indulgencias a quienes acudiesen en dicha fecha a honrar su memoria y orar por su alma. La magnitud de tales celebraciones incluso llevó a replantear el monumento funerario del monarca, dando lugar a un proyecto más ambicioso. La Capilla Real de Sevilla sería la máxima expresión del programa ideológico de Alfonso $\mathrm{X}$, en el que su padre quedaba configurado como ejemplo modélico de la realeza, y se convirtió en un espacio que no sólo servía para conmemorar al difunto monarca, sino como escenario triunfal de la corona castellana ${ }^{53}$. Incluso, resulta plausible suponer que, en 1279, el Sabio tuviera en mente los monumentos a San Luis y Eduardo el Confesor, por lo que quisiera realizar una suntuosa obra que rivalizara con estos ${ }^{54}$. Jofré de Loaysa se refería al monarca como Sanctissimus rex Fernandus, de la misma manera que el ciclo cronístico realizado por Fernán Sánchez Valladolid hablaba de el santo e mucho bien aventurado rey don Ferrando. Aunque la canonización oficial de Fernando III no se produjo hasta el siglo XVII, en la década de 1330 ya se le consideraba santo en Castilla ${ }^{55}$. Sin embargo, L. Fernández señala cómo la visión literaria no tendría una correspondencia visual en las representaciones del monarca, por lo que no estaría completamente aceptada su santidad ${ }^{56}$. De manera similar, el estudio del códice florentino de las Cantigas lleva a R. Sánchez Ameijeiras a señalar cómo la cantiga 292 muestra el fracaso de Alfonso X a la hora de crear un culto en torno a Fernando III. La posterior ilustración del relato, junto con la cantiga 256, respondieron a una nueva campaña de promoción de su figura realizada durante el reinado de Alfonso $\mathrm{XI}^{57}$.

El epitafio de Fernando III, escrito en castellano, latín, árabe y hebreo, expresaba la misma idea. Transcripción en Morales 1979, p. 33.

${ }^{53}$ Sigo aquí la interpretación de Laura Fernández que expone en su sugerente trabajo Fernández 2012.

${ }^{54}$ Sánchez Ameijeiras 2002, p. 263.

${ }^{55}$ García Martínez 1982, p. 73; González Jiménez 1998, p. 3; Linehan 1993, p. 517 . Sobre la canonización de Fernando III véase Rodríguez 1991. El uso ideológico de Fernando III y su santificación durante el reinado de Alfonso XI fue estudiado en Tang 2002-2003.

${ }^{56}$ Fernández 2012, p. 168.

${ }^{57}$ Sánchez Ameijeiras 2002, p. 264. 
Sevilla además era una ciudad muy importante para la monarquía, capaz incluso de oscurecer a Toledo ${ }^{58}$, como se recalcaba en el privilegio de Alfonso X para crear el centro de estudio del árabe y el latín en la localidad, el trato deferente con la que Fernán Sánchez de Valladolid se refería a ella (la muy noble çibdat de Sevilla) en su ciclo cronístico o incluso el epitafio de Fernando III, en el que afirmaba que la ciudad hispalense es cabeça de toda Espanna $^{59}$. Dicha importancia, el fin de la expansión territorial y la presencia allí de Fernando III podrían haber convertido a la catedral sevillana en el mausoleo dinástico de los reyes castellanos si no hubiera sido por los constantes conflictos y problemas de legitimidad que tuvieron que afrontar varios monarcas castellanos durante en este período.

Alfonso X fue enterrado en Sevilla junto a Fernando III y aunque Sancho IV se encargó de acondicionar su sepultura, eligió Toledo como lugar de descanso eterno. Tras su controvertido acceso al trono parece lógico que el Bravo optara por alejarse de la memoria de su padre y ensalzar su figura de manera individual. La posibilidad de recibir sepultura en las Huelgas no resultaba apropiada, ya que su hermano mayor y heredero reposaba allí. La presencia de Fernando de la Cerda vedaba a todo el linaje de Sancho IV la posibilidad de enterrarse en el monasterio burgalés, pues supondría recordar que sus derechos estaban en cuestión. En algún momento después de 1279 se alteró el emblema heráldico de la tumba del difunto infante para intentar borrar los derechos al trono de sus descendientes ${ }^{60}$. Además, parece se buscó convertir las Huelgas en un panteón de la familia real pero no de los monarcas. Por ejemplo, el infante Pedro decidió ser enterrado allí junto a su tío ${ }^{61}$, en lo que parece una decisión nada inocente y previsiblemente pergeñada por María de Molina, figura central en la defensa de los derechos dinásticos de su hijo y nieto ${ }^{62}$.

De ese modo, resulta lógico que el monasterio de las Huelgas no se contemplara como una opción para Fernando IV, del que la crónica decía que no se sabía si debía enterrarse en Toledo o Sevilla aunque acabó siendo sepultado en Córdoba. Alfonso XI fue llevado a Sevilla de manera temporal pero permaneció allí durante más de dos décadas. Pedro I no tuvo ningún interés de trasladar el cuerpo de su padre, que fue situado en la Capilla Real, y es plausi-

\footnotetext{
${ }^{58}$ La amenaza de Sevilla para Toledo se observa en la obra de Jiménez de Rada, cuyo propósito era defender la primacía de la antigua capital visigoda. Linehan 1993, pp. 316-318.

${ }^{59}$ González Jiménez 2004, doc. 142; Rosell 1953b, pp. 204, 296 y 318-319; Morales 1979, p. 33 .

${ }^{60}$ Hernández 2012, pp. 425-426.

${ }^{61}$ AHN, Nobleza, OSUNA, C. 415, D. 2.

${ }^{62}$ Sobre el "molinismo" véase Gómez Redondo 1998, pp. 1225 ss.
} 
ble pensar que prefería que se quedara allí, ya que él mismo tenía la intención de ser enterrado en Sevilla. Tras conseguir que las Cortes de 1362 reconociesen la legalidad de su matrimonio con María de Padilla y de la descendencia que tuvo con ella, Pedro I trasladó sus restos mortales a la ciudad hispalense, instalándolos en la Capilla Real, aunque posteriormente se moverían a la capilla realizada por el monarca a tal efecto, donde también fue sepultado su hijo Alfonso y donde planeaba serlo él mismo ${ }^{63}$. Sin embargo, no pudo ver su deseo cumplido hasta 1877, como se mencionó con anterioridad. Si Pedro I no hubiera sido depuesto, quizás la catedral de Sevilla se hubiera consolidado de manera definitiva como el mausoleo dinástico por antonomasia, pero la victoria de Enrique II lo impidió.

\section{LA CREACIÓN DE NUEVOS ESPACIOS FUNERARIOS EN LA ÉPOCA TRASTÁMARA (1369-1504)}

Al igual que los períodos anteriores, la época Trastámara se caracterizó por la diversidad de los espacios funerarios de la monarquía y por la elección de nuevos lugares de enterramiento, lo que incluso multiplicó dicha dispersión. El deseo de individualizar su memoria personal que tuvieron varios monarcas, ya fuera la necesidad de resaltar una cuestionable legitimidad, la devoción especial por algún sitio en concreto o la recuperación del discurso reconquistador tras la conquista de Granada, explica esta situación.

Pedro I tuvo una predilección absoluta por Sevilla y la ciudad quedó íntimamente ligada a su figura ${ }^{64}$, lo que explica que Enrique II se alejara por completo de ella. En 1371 ordenó el traslado del cuerpo de Alfonso XI a Córdoba y la construcción de la capilla de Villaviciosa para albergar sus restos mortales y los de Fernando IV. Además, encargó la realización de una capilla en la catedral de Toledo, donde él mismo fue enterrado ${ }^{65}$. Dichas disposiciones truncaron, de manera definitiva, las posibilidades de consolidación de Sevilla, pero resultan del todo comprensibles, pues de esa manera honraba el recuerdo de su padre, cumpliendo su voluntad, e individualizaba su memoria personal, en aras de robustecer su cuestionable acceso al trono.

Juan I $(† 1390)$ y Enrique III $(† 1406)$ fueron enterrados también en la conocida como Capilla de los Reyes Nuevos de Toledo, por contraposición a la de los Reyes Viejos donde reposaban Alfonso VII, Sancho III y Sancho IV.

\footnotetext{
${ }^{63}$ Orduña 1994 vol. II, p. 63; Rosell 1953c, p. 565.

${ }^{64}$ Véase Díaz 2007.

${ }^{65}$ Orduña 1994, vol. II, pp. 427-428.
} 
Es difícil establecer si esto respondía a los deseos personales de dichos monarcas o se realizó de manera más o menos espontánea. En cualquier caso resulta una decisión lógica, pues presentaba un discurso que resaltaba la continuidad dinástica, como señalaba el epitafio de Enrique III, donde se recuerda su afiliación familiar ${ }^{66}$. En cualquier caso, Toledo tampoco se consolidó como el panteón regio de los Trastámara. Juan II encargó la realización de una estatua orante suya para que fuera emplazada junto a la tumba de sus antepasados en la Capilla de los Reyes Nuevos, pero optó por un entierro independiente en una institución de su fundación: la Cartuja de Miraflores en Burgos $(† 1454)^{67}$. No parece que hubiera una decisión evidente de intentar afianzar un mausoleo dinástico en Toledo y, en cualquier caso, las elecciones de los futuros monarcas indicarían un deseo de individualizar su figura personal, en lugar de integrarse en una memoria compartida con su linaje.

Enrique IV no eligió ninguno de los espacios funerarios tradicionales de la monarquía castellana y decidió recibir sepultura en el monasterio de Santa María la Real de Guadalupe en $1474^{68}$. Su conflictivo reinado y su amargo final puede que llevaran al monarca a optar por ese alejado retiro. Isabel I (†1504) se encargó de honrar la memoria de su padre con la construcción de su sepulcro en Miraflores, pero optó por otro lugar de enterramiento ${ }^{69}$. La reina escogió Granada, con lo que se reactivó la ideología reconquistadora, tras un largo período de ausencia. Tal elección resultaba a todas luces lógica debido a la importancia excepcional que la toma de dicha ciudad tuvo desde el punto de vista simbólico. Antes de la conquista, los Reyes Católicos habían decidido recibir sepultura en San Juan de los Reyes ${ }^{70}$, monasterio que fundaron para conmemorar su triunfo en la guerra sucesoria, lo que indicaría que desde mucho antes habían resuelto crear un nuevo espacio funerario en el que individualizar su memoria personal. En ese sentido, su controvertido acceso al trono seguramente auspició dicha medida.

La conclusión de la Reconquista no significó tampoco el afianzamiento de un único mausoleo dinástico, pues Granada se convertiría en el panteón familiar de Isabel y Fernando, pero no tendría continuidad después de Juana I. La definitiva consolidación de un espacio funerario preeminente e indiscutido, San Lorenzo de El Escorial, tendría que esperar al reinado de Felipe II y a la configuración de una nueva entidad política: la Monarquía Hispánica.

${ }^{66}$ Morales Cano 2011, pp. 358-359.

${ }^{67}$ Nieto 1995, p. 510; Pérez 2001, p. 253.

${ }^{68}$ Sánchez-Parra 1991, vol. II, p. 477.

${ }^{69}$ Nogales Rincón 2010, pp. 334-335.

${ }^{70}$ Morales Cano 2011, p. 354. 


\section{EL FRACASO DE UNA MEMORIA DINÁSTICA.} CASTILLA FRENTE A OTRAS MONARQUÍAS EUROPEAS.

Los reyes de Castilla y León mostraron un evidente interés por sus lugares de enterramiento, creando (y remodelando) varios panteones, personales o familiares, a lo largo de sus dominios. En ese sentido, no actuaron de manera distinta a sus homólogos peninsulares y ultrapirenaicos, la diferencia radicaba en que ninguno de esos espacios funerarios se consolidó como el lugar de sepultura por antonomasia, mientras que el resto de monarquías sí consiguió afianzar un mausoleo dinástico. Esta diferencia no respondía a una cuestión ontológica o al carácter excepcional de la monarquía castellanoleonesa, sino a las circunstancias históricas concretas que auspiciaron el afianzamiento de estos mausoleos en el período que comprende la segunda mitad del siglo XIII y finales del XIV.

Hasta ese momento, el desarrollo de los espacios funerarios regios en Castilla y León fue muy similar al del resto de monarquías europeas. Tras una primera etapa en la que predominaron los panteones dinásticos, se produjo un cambio en las costumbres de enterramiento a partir de la segunda mitad del siglo XI, en pleno contexto de las reformas papales y los cambios en las formas de religiosidad, hacia la creación de mausoleos personales o familiares, en los que primaba la memoria individual ${ }^{71}$. Por otro lado, todos los reinos experimentaron notables cambios territoriales durante el proceso de consolidación y expansión del poder monárquico que caracterizó el período, lo que multiplicó la dispersión de los espacios funerarios.

En cambio, entre mediados del siglo XIII y finales del XIV, en todos los reinos del Occidente medieval menos en Castilla se produjo la consolidación de un mausoleo dinástico, un lugar de enterramiento privilegiado que se convirtió en la última morada de todos (o casi todos) sus monarcas. SaintDenis se afianzó de manera definitiva durante el reinado de Luis IX mientras que Westminster fue el lugar predilecto de la mayoría de los monarcas ingleses a partir de Enrique III. En la península Ibérica, los monasterios de Poblet y Batalha se erigieron como los panteones dinásticos de Aragón y Portugal a finales del siglo XIV, mientras que los reyes navarros regresaron a Santa María de Pamplona de manera definitiva en esas mismas fechas.

La consolidación de un único mausoleo regio no resultaba una cuestión sencilla, ya que significaba el triunfo de una memoria dinástica compartida frente a los deseos personales de cada monarca de ensalzar su figura

\footnotetext{
${ }^{71}$ Las reformas papales alteraron la costumbre de crear panteones dinásticos, propiciando un cambio en las costumbres de enterramiento. Hallam 1982, p. 371.
} 
individual o su linaje familiar más cercano. Los reyes que murieron en la infancia o que gobernaron durante un período de tiempo muy breve fueron sepultados junto a sus padres, confiriendo cierta continuidad a un mismo lugar de enterramiento. Ese sería el caso de Sancho III, Enrique I o, en cierto modo, Juan I o Enrique III. Por el contrario, si el reinado tenía una destacada duración o relevancia, resultaba lógico que el monarca gustase de sublimar su memoria personal, eligiendo o acondicionando un lugar específico como última morada.

Por tanto, para que un mausoleo regio tuviera éxito debía reunir una serie de características que sublimaran la memoria dinástica hasta el punto de conferirle un prestigio superior al que pudiera alcanzar cualquier otro lugar de enterramiento. Es decir, que el peso del linaje se impusiera a la voluntad que cada monarca tendría de exaltar su figura y reinado de manera individual. Esta problemática no era exclusiva del caso castellano e incluso seguía presente incluso en los mausoleos dinásticos más consolidados, como el caso de Saint-Denis. Así, Luis XI (†1483) prefirió enterrarse en la iglesia que había fundado en Notre-Dame de Cléry, lugar vinculado a la memoria de Juana de $\mathrm{Arco}^{72}$. Por tanto, no era ontológicamente imposible la consolidación de un mausoleo dinástico se produjera en Castilla, hasta se puede incluso especular con que, si el devenir histórico hubiera sido distinto, quizás Sevilla se hubiera podido convertir en el lugar de enterramiento por excelencia de la monarquía. Sin embargo, no fue así, por lo que deben analizarse qué elementos contribuyeron al afianzamiento de un único panteón regio en otros sitios y qué causas lo impidieron en Castilla.

La cercanía del mausoleo regio a la capital del reino, sin duda, constituía un aspecto que contribuiría a su consolidación. En ese sentido, el afianzamiento de Saint-Denis y Westminster está íntimamente relacionado con el auge de París y Londres. La inexistencia de una capital en Castilla, donde varias ciudades competían por ostentar una situación preeminente ${ }^{73}$, dificultaría entonces dicha consolidación, pero no la imposibilitaría, como prueban los casos de Batalha o Poblet.

La presencia de un antecesor que hubiera sido santificado constituía un elemento que también resultaba de gran importancia para asegurar el éxito de un mausoleo regio, al servir de elemento de prestigio para todo su linaje. La presencia de Eduardo el Confesor, canonizado en 1161, y de san Luis, elevado a la santidad en 1298, resultó fundamental para el triunfo de Westminster y

\footnotetext{
${ }^{72}$ Kendall 1971, p. 358.

${ }^{73}$ Véase Arias 2013.
} 
Saint-Denis ${ }^{74}$. Fernando III gozaba de una condición similar, aunque no llegó a estar oficialmente reconocido como tal hasta el siglo XVII. De cualquier modo, no se trataba de una condición absolutamente necesaria, como se observa de nuevo en Aragón, Navarra o Portugal; si bien el prestigio de lo saint Jaime I contribuyó en el caso aragonés, como se mencionó anteriormente.

La práctica del 'doble enterramiento', es decir, la sepultura separada de cuerpo y corazón, también coadyuvó al éxito de los mausoleos dinásticos, algo sobre todo evidente en el caso Saint-Denis. Por ejemplo, Enrique III se enterró en Westminster, pero su corazón fue depositado en 1291 en la abadía de Fontevraud. Carlos II de Navarra diseñó un triple enterramiento en su testamento de 1361: mientras que su cuerpo reposaría en Pamplona, su corazón sería depositado en Santa María de Ujué y sus entrañas en Santa María de Roncesvalles. De manera similar, los reyes franceses tenían SaintDenis como última morada pero entregaban sus corazones a alguna institución religiosa que habían fundado o a la que tenían especial devoción ${ }^{75}$. De este modo, se permitía conciliar el deseo de individualizar la memoria personal de un monarca con la idea de continuidad dinástica. Sin embargo, esta práctica de realizar un doble (o incluso triple) enterramiento tuvo un uso en Castilla muy limitado. El único monarca que siguió este ritual fue Alfonso X, cuyo cuerpo fue enterrado en Sevilla pero su corazón fue llevado en Murcia, reino que había conquistado cuando era infante ${ }^{76}$. El Sabio fue un rey excepcional desde muchos puntos de vista y dicha práctica, sin ningún antecedente en la tradición castellana, no tuvo continuidad. En todo caso, tampoco se realizó en Portugal ni en Aragón, pues no se cumplió la voluntad de Juan I ${ }^{77}$.

Todos estos elementos que, sin duda, contribuyeron al éxito de SaintDenis y Westminster no estaban presentes en el caso castellano, pero tampoco en el aragonés o el portugués, donde sí se consolidaron mausoleos regios. Por tanto, en última instancia, el fracaso de la memoria dinástica respondería a la primacía de la memoria personal. El deseo de individualizar su figura tuvo mucha más influencia para los monarcas castellanos que la reivindicación de su linaje.

De ese modo, el discurso ideológico de la Reconquista vuelve a aparecer de nuevo. La voluntad de los monarcas castellanos de ensalzar sus gestas militares y los grandes hitos bélicos de su reinado actuaría en detrimento de

\footnotetext{
${ }^{74}$ Hallam 1982, pp. 362-363.

${ }^{75}$ Palliser 2004, p. 2; Osés 2008, pp. 320-321; Warntjes 2012, pp. 254-255. Véase también Bande 2009.

${ }^{76}$ Posiblemente, el monarca tomó esta práctica de la monarquía francesa. Warntjes 2012 , p. 227.

${ }^{77}$ Serrano 2015a, p. 422.
} 
una memoria dinástica común, al potenciar su recuerdo individual. La guerra contra los musulmanes constituía un elemento fundamental en el entramado ideológico y propagandístico de los reyes de Castilla, pero no tuvo tanta importancia a la hora de condicionar sus lugares de enterramiento. Fernando I o Alfonso VII tuvieron presente un ideal neogoticista en sus sepulturas. Sin embargo, la elección de los lugares de enterramiento no estuvo tan influida por el discurso ideológico de restauración del perdido reino visigodo como por una cuestión territorial en los siglos XI y XII. Los monarcas optaron por situar su última morada en los centros donde radicaba su poder. Quizás el ejemplo más evidente sea el de Alfonso VI, que prefirió recibir sepultura en Sahagún a pesar de haber conquistado Toledo, con todo lo que ello significaba. Las elecciones de Alfonso X y Alfonso XI estuvieron motivadas por el deseo de ensalzar sus logros militares, pero, en la práctica, no se llegaron a ejecutar tal y cómo deseaban. El Sabio permaneció en Sevilla, aunque su corazón sí fue depositado en Murcia, mientras que Alfonso XI fue trasladado a la catedral de Córdoba primero y, finalmente, a San Hipólito en 1736. Los únicos monarcas que escogieron como última morada las ciudades que conquistaron fueron Fernando III e Isabel la Católica. De ese modo, se observa que la elección del lugar de enterramiento estuvo influida por el discurso ideológico de la Reconquista sólo en momentos muy concretos y de manera muy desigual, por lo que resulta difícil considerar que fue el principal motivo que impidió la consolidación de un mausoleo dinástico.

En cambio, las crisis de legitimidad que tuvieron que afrontar varios monarcas castellanos sí condicionaron de manera más evidente la elección de sus lugares de enterramiento, pues su cuestionable acceso al trono les impelió a resaltar su memoria individual. Tratar de definir la legitimidad de un monarca medieval es una cuestión difícil, pues constituye una concepción muy voluble en la que intervienen numerosos factores biológicos y políticos, no se limita a la mera norma dinástica ${ }^{78}$. Los conflictos de legitimidad no fueron exclusivos de Castilla, pero sí se produjeron de manera muy frecuente, casi cíclica, y en un momento clave. Durante el período en que el resto de las monarquías afianzaron sus mausoleos dinásticos, la legitimidad de varios reyes castellanos estuvo en entredicho, lo que incidió en la multiplicación de los espacios funerarios.

En Castilla, la presencia de Fernando de la Cerda en las Huelgas de Burgos condicionaba el enterramiento de los sucesores de Alfonso $\mathrm{X}$ en dicho lugar, ya que sería un recordatorio de su cuestionada legitimidad. De esa manera, Sevilla y Toledo aparecían como los dos espacios funerarios más desta-

${ }^{78}$ Rodríguez 2004, p. 30. Véase también Given-Wilson 2004. 
cados, debido a la importancia y fuerza simbólica de ambas ciudades para la Corona. Parece plausible pensar que la catedral de Sevilla reunía las características ideales para afianzarse como el mausoleo dinástico, pero la conflictiva situación política lo impidió en dos ocasiones, en 1282 y en 1369. En estos dos momentos, la rebelión de Sancho frente a su padre y la deposición de Pedro I, se observa una clara cesura respecto a la etapa anterior. La necesidad de Sancho IV y Enrique II de legitimar su posición debido a su controvertido acceso al trono les llevaron a habilitar nuevos espacios funerarios para ensalzar sus figuras e individualizar su memoria, lo que imposibilitó una hipotética consolidación de Sevilla como el lugar de enterramiento regio por excelencia.

Se puede argumentar que, si la legitimidad personal de un monarca estaba cuestionada, quizás la mejor manera de fortalecerla sería vinculando su figura a la memoria de sus antecesores, como en Aragón o Navarra. Sin embargo, no en todos sitios sucedió así, ya que en otros casos se optó por individualizar su figura, lo que, de manera evidente, no suponía una repulsa de su linaje. Sancho IV elaboró la sepultura de su padre en la catedral de Sevilla y Enrique II ordenó el traslado de Alfonso XI a Córdoba, honrando su recuerdo, pero ambos mostraron una voluntad inequívoca de diferenciarse de su memoria al crear sus propias capillas funerarias. Dicha situación no era exclusiva de Castilla. En Portugal, Dinis I abandonó el monasterio de Alcobaça por el de Odivelas para fundar su poder en base a una nueva legitimidad, tras el derrocamiento de su tío Sancho II por su padre, Alfonso III. De manera similar, la dinastía de Avís creó su propio panteón en Batalha. En Inglaterra, Enrique IV, cuyo acceso al trono tras la deposición de Ricardo II fue cuestionado durante todo su reinado, decidió a recibir sepultura en Canterbury junto a santo Tomás Becket ${ }^{79}$.

Queda por último la cuestión de por qué la antigua capital visigoda no se convirtió en el mausoleo regio tras el cambio dinástico de 1369, de manera similar al monasterio de Batalha en Portugal. No resulta tan sencillo ofrecer una respuesta a esta decisión, pero se pueden plantear algunas ideas: la nueva dinastía no tenía un hito sobre el que justificar su posición tan importante como la victoria de Aljubarrota; durante el reinado de Juan I se cambió el discurso de legitimación de los Trastámara, dejando de lado la figura de Enrique II por la de Juana Manuel y repudiando al linaje de Sancho IV, que también se hallaba en Toledo ${ }^{80}$; y los constantes conflictos e inestabilidad política durante los reinados de Juan II y Enrique IV, que junto al controvertido acceso al trono de Isabel la Católica supondría un incentivo para individualizar la memoria personal en lugar de la dinástica.

\footnotetext{
${ }^{79}$ Supra notas 42 y 44.

${ }^{80}$ Véase Gómez Redondo 2002.
} 
Ningún espacio funerario en Castilla reunía las condiciones ideales de Westminster o Saint-Denis para convertirse en el mausoleo regio por excelencia, pero, en última instancia, la no consolidación de ningún lugar de enterramiento respondió a los deseos de los monarcas castellanos de individualizar su figura. Por tanto, la dispersión de los espacios funerarios es el resultado del fracaso de la memoria dinástica en Castilla, donde los monarcas optaron por exaltar su memoria personal en lugar de la pertenencia a un linaje que, en última instancia, podía ser discutido.

\section{BIBLIOGRAFÍA CITADA}

Abad Castro, Concepción (2001), Espacios y capillas funerarias de carácter real, en Bango Torviso, Isidro (ed.), Maravillas de la España medieval: Tesoro sagrado y monarquía, Valladolid, Junta de Comunidades de Castilla y León, vol. I, pp. 63-72.

Alonso Álvarez, Raquel (2003), De Carlomagno al Cid: la memoria de Fernando III en la Capilla Real de Sevilla, en Fernando III y su tiempo (1201-1252). VIII Congreso de Estudios Medievales, León, Fundación Sánchez Albornoz, pp. 471-484.

Alonso Álvarez, Raquel (2005), Los enterramientos de los reyes visigodos, en Fundamentos medievales de los particularismos hispánicos. IX Congreso de Estudios Medievales 2003, León, Fundación Sánchez Albornoz, pp. 361-376.

Alonso Álvarez, Raquel (2007), Los enterramientos de los reyes de León y Castilla hasta Sancho IV, "e-Spania" 3, http://e-spania.revues. org/109 [consulta 19/12/2012].

Alonso Álvarez, Raquel (2012), Enterramientos regios y panteones dinásticos en los monasterios medievales castellano-leoneses, en Monasterios y monarcas: fundación, presencia y memoria regia en los monasterios hispanos medievales, Aguilar de Campoo, Fundación Santa María la Real - Centro de Estudios del Románico, pp. 201-223.

Arias Guillén, Fernando (2012), El linaje maldito de Alfonso X. Conflictos en torno a la legitimidad regia en Castilla (c. 1275-1390), "Vínculos de Historia" 1, pp. 147-163.

Arias Guillén, Fernando (2013), A Kingdom without a Capital? Itineration and spaces of royal power in Castile (c. 1252-1350), "Journal of Medieval History" 39/4, pp. 456-476.

Bande, Alexander (2009), Le cœur du roi. Les Capétiens et les sépultures multiples XIIIe-XVe siècles, París, Tallandier. 
Benavides, Antonio (1860), Memorias de Don Fernando IV de Castilla, 2 vols., Madrid, Imprenta J. Rodríguez.

Boto Varela, Gerardo (2004), Sobre reyes y tumbas en la catedral de León. Discursos visuales de poder político y honra sacra, en Yarza, Joaquín; Herráez, María Victoria; Boto, Gerardo (eds.), La Catedral de León en la Edad Media. Congreso Internacional. Actas, León, Universidad de León, pp. 305-365.

Boto Varela, Gerardo (2012), Aposentos de la memoria dinástica. Mudanza y estabilidad en los panteones regios leoneses (1157-1230), "Anuario de Estudios Medievales" 42/2, pp. 535-565.

Buesa Conde, Domingo (1996), Sancho Ramírez, rey de aragoneses y pamploneses (1064-1094), Zaragoza, Caja de Ahorros y Monte de Piedad de Zaragoza, Aragón y Rioja.

Burden, Joel (2003), How do you Bury a Deposed King? The Funeral of Richard II and the Establishment of Royal Authority in 1400, en Dodd, Gwilyn; Biggs, Douglas (eds.), Henry IV: The Establishment of the Regime, 1399-1406, Woodbridge, Boydell, pp. 35-53.

Cabrera Sánchez, Margarita (2001), Funerales regios en la Castilla bajomedieval, "Acta historica et archaeologica mediaevalia" 22, pp. 537-564.

Cabrera Sánchez, Margarita (2011), La muerte de los miembros de la realeza hispánica medieval a través de los testimonios historiográficos, "En la España medieval" 34, pp. 97-132.

Calderón Medina, Inés (2011), La memoria de los reyes de León (1157-1230), en Martínez, Pascual; Rodríguez, Ana (eds.), La construcción medieval de la memoria regia, Valencia, Universitat de València, pp. 169-188.

Carpenter, David (1996), The Burial of King Henry III, the Regalia and Royal Ideology, en The Reign of Henry III, Londres, Hambledon Press, pp. 427-59.

Cerda, José Manuel (2012), Leonor Plantagenet y la consolidación castellana en el reinado de Alfonso VIII, "Anuario de Estudios Medievales" 42/2, pp. 629-652.

Cusimano, Richard y Moorhead, John (eds.) (1992), The Deeds of Louis the Fat, Washington, Catholic University of America Press.

Del Arco y Garay, Ricardo (1945), Sepulcros de la Casa Real de Aragón, Madrid, CSIC.

Del Arco y Garay, Ricardo (1954), Sepulcros de la Casa Real de Castilla, Madrid, CSIC.

Dectot, Xabier (2004), Les cimetières aux rois et leur évolution en León et en Castille du XIe au XIIIe siècle, "Hortus Artium Medievalium. 
Journal of the International Research Center for Late Antiquity and Middle Ages" 10, pp. 55-62.

Dectot, Xabier (2005), Tombeaux et pouvoir royal dans le León autour de l'an mil, en Deswarte, Thomas; Sénac, Philippe (dirs.), Guerre, pouvoirs et idéologies dans l'Espagne chrétienne aux alentours de l'an mil. Actes du Colloque international organisé par le Centre d'Etudes Supérieures de Civilisation Médiévale Poitiers-Angoulême septembre 2002, Turnhout, Brepols, pp. 81-96.

Deswarte, Thomas (2003), De la destruction à la restauration. L'idéologie du royaume d'Oviedo-León (VIIe-XIe siècles), Turnhout, Brepols.

Díaz Martín, Luis Vicente (2007), Pedro I el Cruel (1350-1369), Gijón, Trea. Duffy, Mark (2003), Royal Tombs of Medieval England, Stroud, Tempus.

Erlande-Brandenburg, Alain (1975), Le Roi est Mort. Études sur les funérailles, les sépultures et les tombeaux des rois de France jusqu' à la fin du treizième siècle, Ginebra, Droz.

Estepa Díez, Carlos (1989), Formación y consolidación del feudalismo en Castilla y León, en En torno al feudalismo hispánico. I Congreso de Estudios Medievales, León, Fundación Sánchez Albornoz, pp. 157-256.

Estepa Díez, Carlos; Álvarez Borge, Ignacio; Santamarta Luengos, José María (2011), Poder real y sociedad: estudios sobre el reinado de Alfonso VIII (1158-1214), León, Universidad de León.

Fernández Fernández, Laura (2012), Muy noble, et mucho alto et mucho honrado. La construcción de la imagen de Fernando III, en Ayala Martínez, Carlos; Ríos Saloma, Martín (coords.), Fernando III tiempo de Cruzada, Madrid, Sílex, pp. 137-174.

Garcia, Charles (2009), Itinérance de la cour et attaches sédentaires sous Alphonse VI et Urraque Ire, "e-Spania" 8, http://e-spania.revues. org/18692 [consulta 14/12/2012].

García Fernández, Manuel (1988), Regesto documental andaluz de Alfonso XI (1312-1350), "Historia, instituciones, documentos" 15 pp. 1-126.

García Fitz, Francisco (2010), La Reconquista, Granada, Universidad de Granada.

García Martínez, Antonio (ed.) (1982), Crónica de los reyes de Castilla, Murcia, Academia Alfonso X el Sabio.

Given-Wilson, Chris (2004), Legitimation, Dessignation and Succession to the Throne in Fourteenth Century England, en Alfonso, Isabel; Kennedy, Hugh; Escalona, Julio (eds.), Building Legitimacy. Political Discourses and Forms of Legitimation in Medieval Societies, Leiden - Boston, Brill, pp. 89-105. 
Given-Wilson, Chris (2009), The Exequies of Edward III and the Royal Funeral Ceremony in Late Medieval England, "English Historical Review" 124/507, pp. 257-282.

Gómez Bárcena, María Jesús (2005), El panteón real de las Huelgas de Burgos, en Yarza Luaces, Joaquín (coord.), Vestiduras ricas. El monasterio de Las Huelgas y su época (1170-1340), Madrid, Patrimonio Nacional, pp. 51-72.

Gómez Redondo, Fernando (1998), Historia de la prosa medieval castellana. I La creación del discurso político: el entramado cortesano, Madrid, Cátedra.

Gómez Redondo, Fernando (2002), Don Juan Manuel, Trastámara, "Cahiers de Linguistique et de Civilisation Hispaniques Medievales" 25, pp. 163-181.

González Jiménez, Manuel (ed.) (1998), Crónica de Alfonso X, Murcia, Real Academia Alfonso X el Sabio.

González Jiménez, Manuel (2004), Alfonso X el Sabio, Madrid, Ariel.

Guiance, Ariel (1998), Los discursos sobre la muerte en la Castilla medieval (siglos VII-XV), Valladolid, Consejería de Educación y Cultura.

Gutiérrez Baños, Fernando (1997), Las empresas artísticas de Sancho IV el Bravo, Burgos, Consejería de Educación y Cultura.

Hallam, Elizabeth (1982), Royal Burial and the Cult of Kingship in France and England, 1060-1330, "Journal of Medieval History" 8, pp. 359-380.

Hernández, Francisco J. (2012), Two Weddings and a Funeral: Alfonso X's Monuments in Burgos, "Hispanic Research Journal" 13/5, pp. 407-433.

Kendall, Paul (1971), Louis XI, Londres, Allen and Unwin.

Laguna Paúl, Teresa (2001), La capilla de los reyes de la primitiva Catedral de Santa María de Sevilla y las relaciones de la Corona castellana con el cabildo hispalense en su etapa fundacional (1248-1285), en Bango Torviso, Isidro (ed.), Maravillas de la España medieval: tesoro sagrado y monarquía, Valladolid, Junta de Comunidades de Castilla y León, vol. I, pp. 235-249.

Linehan, Peter (1993), History and the historians of Medieval Spain, Nueva York, Oxford University Press.

Martínez de Aguirre, Javier (1995), La primera escultura funeraria gótica en Sevilla: la Capilla Real y el Sepulcro de Guzmán el Bueno (12481320), "Archivo español de arte" 68/270, pp. 111-130.

Mattoso, José (1995), O poder e a morte "Anuario de Estudios Medievales" 25/2, pp. 395-428.

Menéndez Pidal, Ramón (ed.) (1977), Primera Crónica General de España, 2 vols., Madrid, Gredos. 
Menjot, Denis (2003), Un cristiano que muere siempre. Los funerales reales en Castilla a finales de la Edad Media, en Dominar y controlar en Castilla en la Edad Media, Málaga, Centro de Ediciones de la Diputación de Málaga, pp. 48-71.

Miranda García, Fermín (2008), La realeza navarra y sus rituales en la Alta Edad Media (905-1234), en Ceremonial de la coronación, unción y exequias de los reyes de Inglaterra. Estudios complementarios, Pamplona, Gobierno de Navarra, pp. 253- 277.

Miranda García, Fermín (2014), Los espacios del rey muerto. Sepulcros y panteones regios en Navarra, siglos X-XIV, en La Construcción Medieval del Espacio Regio. Congreso realizado en Pamplona los días 20, 21 y 22 de noviembre de 2014, [S.1., s.n.].

Mitre Fernández, Emilio (1988), La muerte del rey: la historiografía hispánica y la muerte entre las élites, "En la España Medieval" 11, pp. 167-183.

Morales, Alfredo (1979), La Capilla Real de Sevilla, Sevilla, Diputación Provincial.

Morales Cano, Sonia (2011), La escultura funeraria gótica en la provincia de Toledo, "Anales de historia del arte" Núm. extra 1, pp. 353-364.

Nieto Soria, José Manuel (1993), Ceremonias de la realeza. Propaganda y legitimación en la Castilla Trastámara, Madrid, Nerea.

Nieto Soria, José Manuel (1995), Propaganda política y poder real en la Castilla Trastámara. Una perspectiva de análisis, "Anuario de Estudios Medievales" 25/2, pp. 489-515.

Nieto Soria, José Manuel (1997), Origen divino, espíritu laico y poder real en la Castilla del siglo XIII, "Anuario de Estudios Medievales" 27/1, pp. 43-102.

Nieto Soria, José Manuel (2006), La monarquía como conflicto de legitimidades, en Nieto Soria, José Manuel (dir.), La monarquía como conflicto en la Corona Castellano-Leonesa (c. 1230-1504), Madrid, Sílex, pp. 13-71.

Nogales Rincón, David (2010), La memoria funeraria en el marco de la confrontación política, en Nieto Soria, José Manuel (dir.), El conflicto en escenas. La pugna política como representación en la Castilla bajomedieval, Madrid, Sílex, pp. 323-355.

Núñez Rodríguez, Manuel (1999), Muerte coronada. El mito de los reyes de la catedral compostelana, Santiago, Universidad de Santiago de Compostela.

Orduña, Germán, (ed.) (1994), Crónica del rey don Pedro y del rey don Enrique, su hermano, hijos del rey don Alfonso Onceno, Buenos Aires, Seminario de Edición y Crítica textual. Incipit, dos vols.

Osés Urricelqui, Mercedes (2008), El ritual de la realeza navarra en los siglos XIV y XV: coronaciones y funerales, en Ramírez Vaquero, Eloísa 
(coord.), Ceremonial de la coronación, unción y exequias de los reyes de Inglaterra. Estudios complementarios, Pamplona, Gobierno de Navarra, pp. 305-321.

Palliser, David (2004), Royal Mausolea in the Long Fourteenth Century (1272-1422), en Ormrod, William Mark (ed.), Fourteenth Century England III, Woodbridge, Boydell, pp. 1-16.

Pascua Echegaray, Esther (2001), South of the Pyrenees: kings, magnates and political bargaining in Twelfth-century Spain, "Journal of Medieval History" 27, pp. 101-120.

Pérez Grande, Margarita (2001), Los reyes y la catedral de Toledo, en Bango Torviso, Isidro (ed.), Maravillas de la España medieval: tesoro sagrado y monarquía, Valladolid, Junta de Comunidades de Castilla y León, vol. I, pp. 253-259.

Ramírez y De las Casas Deza, Luis María (1856), Indicador cordobés: manual histórico topográfico de la ciudad de Córdoba, Córdoba, Imprenta y Litografía de D. Fausto García Tena.

Ramírez Vaquero, Eloísa (2008), Reinar en Navarra en la Baja Edad Media, en Eadem, Ceremonial de la coronación, unción y exequias de los reyes de Inglaterra. Estudios complementarios, Pamplona, Gobierno de Navarra, pp. 279-303.

Rodríguez López, Ana (1991), Fernando III el Santo (1217-1252). Evolución historiográfica, canonización y utilización política, en Miscellània en Homenatge al P. Agustí Altisent, Tarragona, Diputació de Tarragona, pp. 573-588.

Rodríguez López, Ana (2004), Sucesión regia y legitimidad política en Castilla en los siglos XII y XIII. Algunas consideraciones sobre el relato de las crónicas latinas castellano-leonesas, "Cahiers de Linguistique et de Civilisation Hispaniques Medievales" 16, pp. 21-41.

Rosell, Cayetano (ed.) (1953a), Crónicas de los reyes de Castilla: desde Don Alfonso el Sabio, hasta los Católicos Don Fernando y Doña Isabel. Crónica de Sancho IV, Madrid, Atlas, vol. I, pp. 69-90.

Rosell, Cayetano (ed.) (1953b), Crónicas de los reyes de Castilla: desde Don Alfonso el Sabio, hasta los Católicos Don Fernando y Doña Isabel. Crónica de Alfonso XI, Madrid, Atlas, vol. I, pp. 173-392.

Rosell, Cayetano (ed.) (1953c), Crónicas de los reyes de Castilla: desde Don Alfonso el Sabio, hasta los Católicos Don Fernando y Doña Isabel. Crónica de Pedro I, Madrid, Atlas, vol. I, pp. 394-568.

Rucquoi, Adeline (1992), De los reyes que no son taumaturgos: los fundamentos de la realeza en España, "Relaciones. Estudios de historia y sociedad" 13/51, pp. 55-100. 
Sánchez Ameijeiras, Rocío (1998), El çementerio real de Alfonso VIII en Las Huelgas de Burgos, "Semata: Ciencias sociais e humanidades" 10, pp. 77-109.

Sánchez Ameijeiras, Rocío (2002), La fortuna sevillana del códice florentino de las Cantigas: tumbas, textos e imágenes, "Quintana: revista de estudios do Departamento de Historia da Arte" 1, pp. 257-273.

Sánchez Ameijeiras, Rocío (2005), The Eventful Life of the Royal Tombs of San Isidoro de León, en Martin, Therese; Harris, Julie (eds.), Church, State, Vellum, and Stone: Essays on Medieval Spain in Honor of John Williams, Leiden, Brill, pp. 479-520.

Sánchez-Parra, María Pilar (ed.) (1991), Crónica anónima de Enrique IV de Castilla 1454-1474: (Crónica castellana), 2 vols., Madrid, Editorial de la Torre.

Serrano Coll, Marta (2015a), Effigies Regis Aragonum. La imagen figurativa del rey de Aragón en la Edad Media, Zaragoza, Diputación de Zaragoza - Instituto Fernando el Católico (en prensa).

Serrano Coll, Marta (2015b), Visualizing the Monarchy Power in the XIVth Century: An Example of Narrativity through Chronicle Texts and Funereal Images in the Iberian Peninsula, en Hortus Artium Medievalium. Power through Visual Narrativity in Late Medieval Europe (13th-15th century). An interdisciplinary Approach (en prensa).

Tamburri Bariáin, Pascual (1996), Liturgia de la realeza bajomedieval, en Martín Duque, Ángel (dir.), Signos de Identidad Histórica para Navarra, Pamplona, Caja de Ahorros de Navarra, pp. 387-398.

Tang, Frank (2002-2003), El Rex Fidelissimus: rivalidad hispano-francesa en la Castilla de Alfonso XI (1312-1350), "Studia historica. Historia medieval" 20-21, pp. 189-206.

Valle Pérez, José Carlos (2005), La construcción del monasterio de las Huelgas, en Yarza Luaces, Joaquín (coord.), Vestiduras ricas. El monasterio de Las Huelgas y su época (1170-1340), Madrid, Patrimonio Nacional, pp. 35-50.

Varela, Javier (1990), La muerte del rey. El ceremonial funerario de la monarquía española (1500-1885), Madrid, Turner.

Vasconcelos Vilar, Hermenegildo (2012), Lineage and Territory: Royal Burial Sites in the Early Portuguese Kingdom, en Spief, Karl-Heinz; Warntjes, Immo (eds.), Death at Court, Wiesbaden, Harrassowitz, pp. 159-170.

Walker, Rose (2001), Images of royal and aristocratic burial in northern Spain, c. 950-c. 1250, en Van Houts, Elizabeth (ed.), Medieval memories. Men, women and the past, Harlow, Longman, pp. 150-172. 
Walker, Rose (2005), Leonor of England, Plantagenet queen of King Alfonso VIII of Castile, and her foundation of the Cistercian abbey of Las Huelgas. In imitation of Fontevraud?, "Journal of Medieval History" 31, pp. 346-368.

Warntjes, Immo (2012), Programatic Double Burial (Body and Heart) of the European High Nobility, c. 1200-1400. Its Origin, Geography, and Fuctions, en Spief, Karl-Heinz; Warntjes, Immo (eds.), Death at Court, Wiesbaden, Harrassowitz, pp. 159-170.

Yarza Luaces, Joaquín (2005). Monasterio y palacio del rey, en Yarza Luaces, Joaquín (coord.), Vestiduras ricas. El monasterio de Las Huelgas y su época (1170-1340), Madrid, Patrimonio Nacional, pp. 15-34.

Fecha de recepción del artículo: febrero 2013

Fecha de aceptación y versión final: diciembre 2014 